\title{
Climatology and Potential Effects of an Emergency Outlet, Devils Lake Basin, North Dakota
}

\section{Introduction}

The Devils Lake Basin is a 3,810square-mile subbasin (fig. 1) in the Red River of the North Basin. At an elevation of about 1,447 feet above sea level, Devils Lake begins to spill into Stump Lake; and at an elevation of about 1,459 feet above sea level, the combined lakes begin to spill through Tolna Coulee into the Sheyenne River (fig. 2).

Since the end of glaciation about 10,000 years ago, Devils Lake has fluctuated between spilling and being dry. Research by the North Dakota Geological Survey indicates Devils Lake has overflowed into the Sheyenne River at least twice during the past 4,000 years and has spilled into the Stump Lakes several times (Bluemle, 1991; Murphy and others, 1997). John Bluemle, North Dakota State Geologist, concluded the natural condition for Devils Lake is either rising or falling, and the lake should not be expected to remain at any elevation for a long period of time.

Recent conditions indicate the lake is in a rising phase. The lake rose 24.7 feet from February 1993 to August 1999, and flood damages in the Devils Lake Basin have exceeded $\$ 300$ million. These damages, and the potential for additional damages, have led to an effort to develop an outlet to help control lake levels. Therefore, current and accurate climatologic and hydrologic data are needed to assess the viability of the various options to reduce flood damages at Devils Lake.

\section{Climatology}

\section{Nature of Climate Variability}

Devils Lake responds directly to climate variability across the region. This climate variability generally can be regarded as the movement of the jet stream from season to season and from

year to year. As weather systems move, they are guided along the jet stream.

Climate variability results from a long-

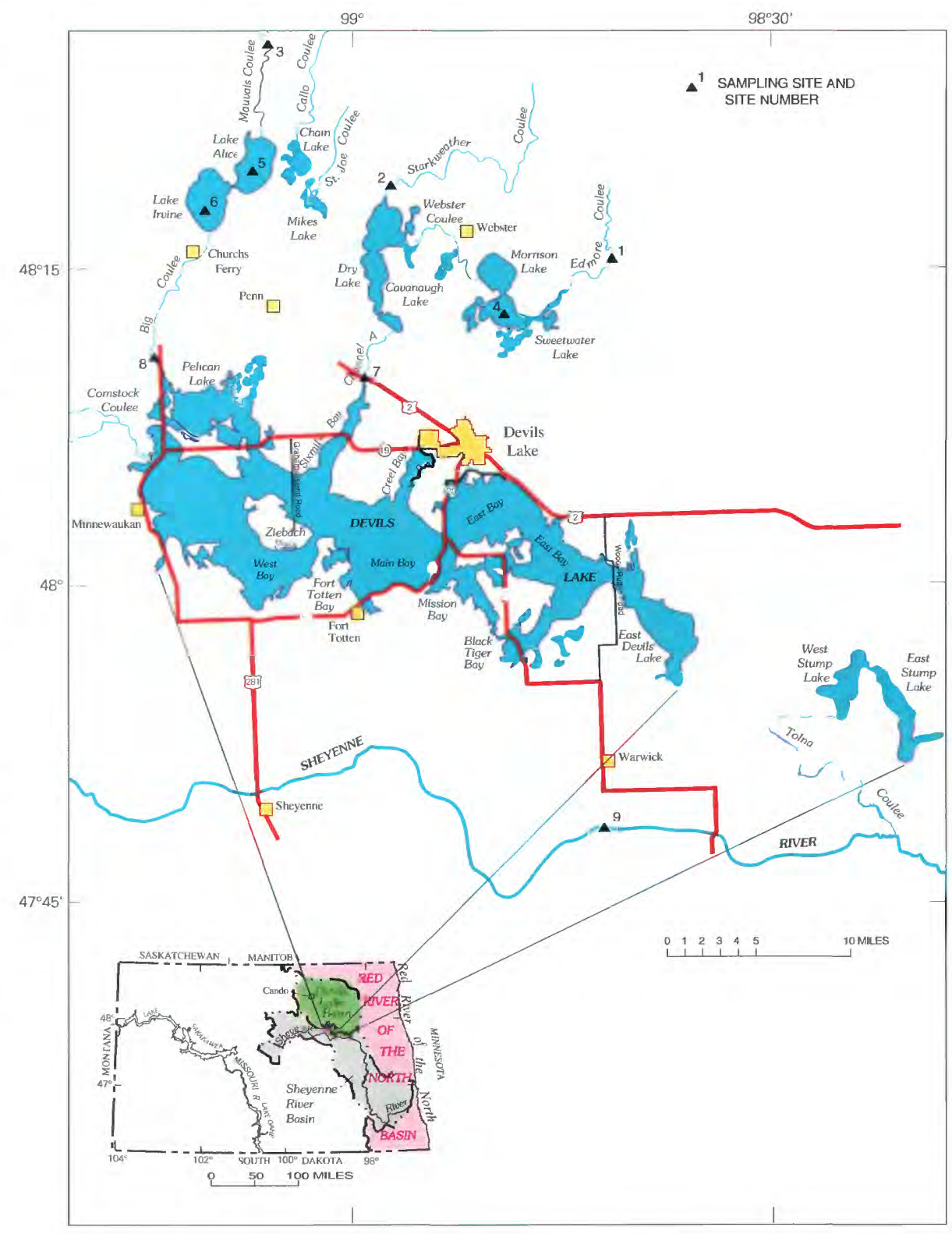

Figure 1. Location of the Devils Lake Basin, Devils Lake and Stump Lakes, and the Sheyenne River. 


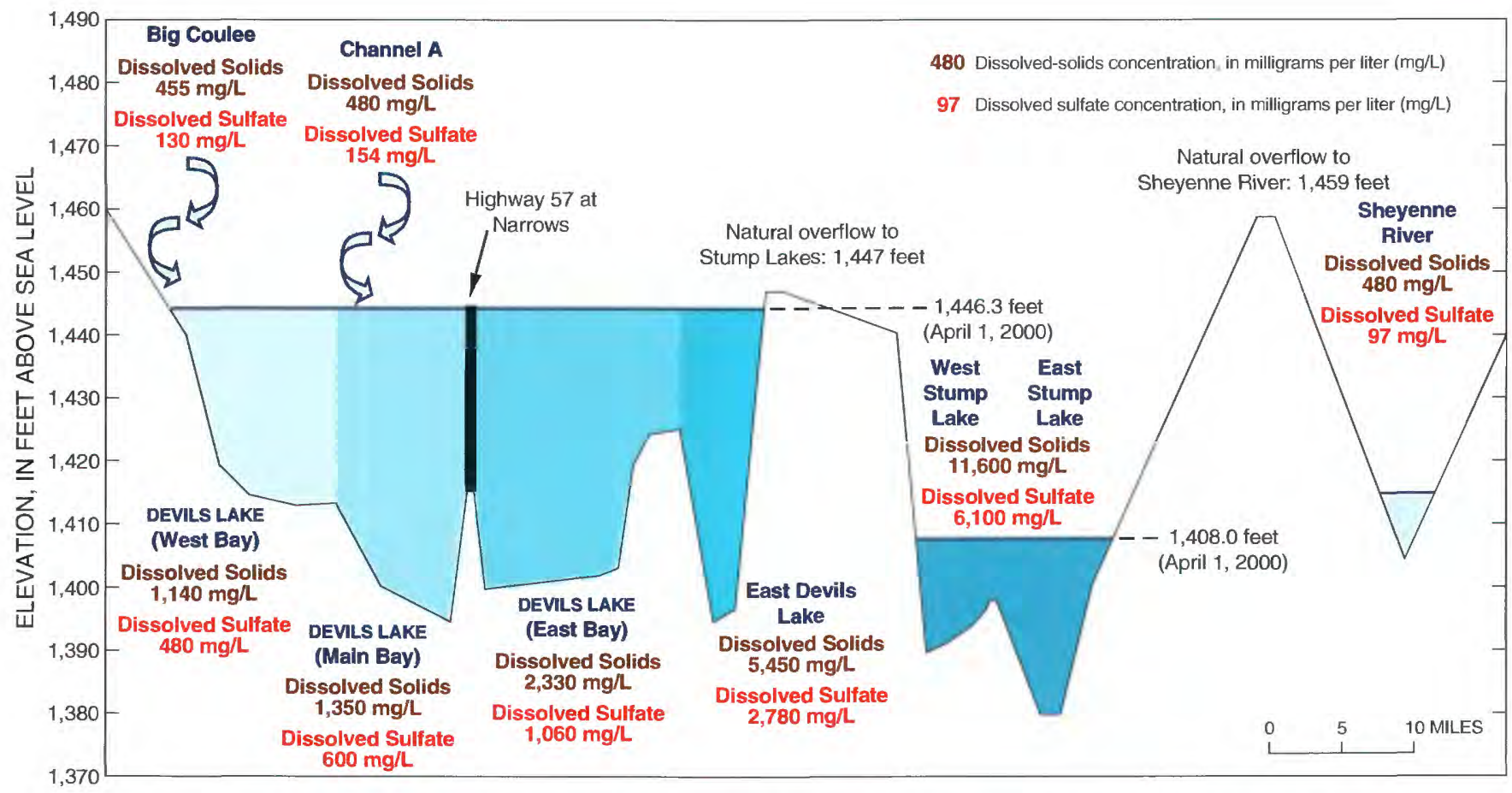

Figure 2. Spill elevations of Devils Lake and Stump Lakes; lake levels on April 1, 2000; and dissolved-solids and sulfate concentrations for tributary inflows, lake water, and Sheyenne River flow.

term shift in circulation patterns of the jet stream. As the circulation patterns shift, precipitation and temperature patterns also shift.

Global atmospheric circulation patterns are driven predominantly by variations in sea-surface temperatures. The most noticeable of these variations, known as El Nino, occurs in the equatorial Pacific and accounts for the dramatic variations in precipitation patterns along the western equatorial regions of South America. Across the plains of the northern United States and southern Canada, El Nino and its cold counterpart--La Nina--produce variations in precipitation and temperature patterns primarily in the winter months. However, long-term variations in annual precipitation and temperature patterns across the region also occur as a result of variations in the tropical sea-surface temperatures. These long-term variations often last for decades and are instrumental in the occurrence of flood and drought conditions across the Devils Lake Basin and elsewhere.

When El Nino and La Nina are strong, their interaction with global circulation patterns results in strong jet-stream windspeeds and violent storms along the jet- stream path. The relation between seasurface temperatures and the global circulation patterns results in long-term shifts in the position of the jet stream. Therefore, the position of the jet stream is important in determining the precipitation and temperature patterns in the Devils Lake Basin. The variations in these patterns across the Devils Lake Basin over time are the result of changing global circulation patterns.

\section{Atmospheric Weather Patterns Before 1977}

Before the late 1970's, the activity of El Nino was subdued, and few variations occurred in the precipitation and temperature patterns in the Devils Lake Basin. The average seasonal precipitation values for 1950-77 varied from year to year but had no definite trends (fig. 3). The average annual temperatures for 1950-77 were slightly warmer than temperatures after 1977, and a sharp temperature contrast occurred between the winter and summer extremes.

\section{Atmospheric Weather Patterns from 1977 to the Present}

Since the late 1970 's, the activity of El Nino has been greater than at any other time during the 20th century. This heightened El Nino activity, and the subsequent movement of the jet stream farther north, has resulted in an increased frequency of moisture-bearing storms from the Gulf of Mexico across the Devils Lake Basin, particularly during May and June and during the early fall.

\section{Climate Outlook for the Future}

The duration of the present wet conditions cannot be determined definitely because of the complex interactions between global weather factors. Although La Nina conditions could bring some periodic relief from persistent, excessive precipitation, long-range climate models indicate generally wet conditions for the near future. Also, because the factors causing the wet conditions are global in scale, the transition from wet conditions to dry conditions may require years. Therefore, generally cool and wet conditions similar to those that occurred from 1977 to the present likely will continue beyond the first decade of the new century. Significant year-to-year variations in precipitation also will continue to occur. 


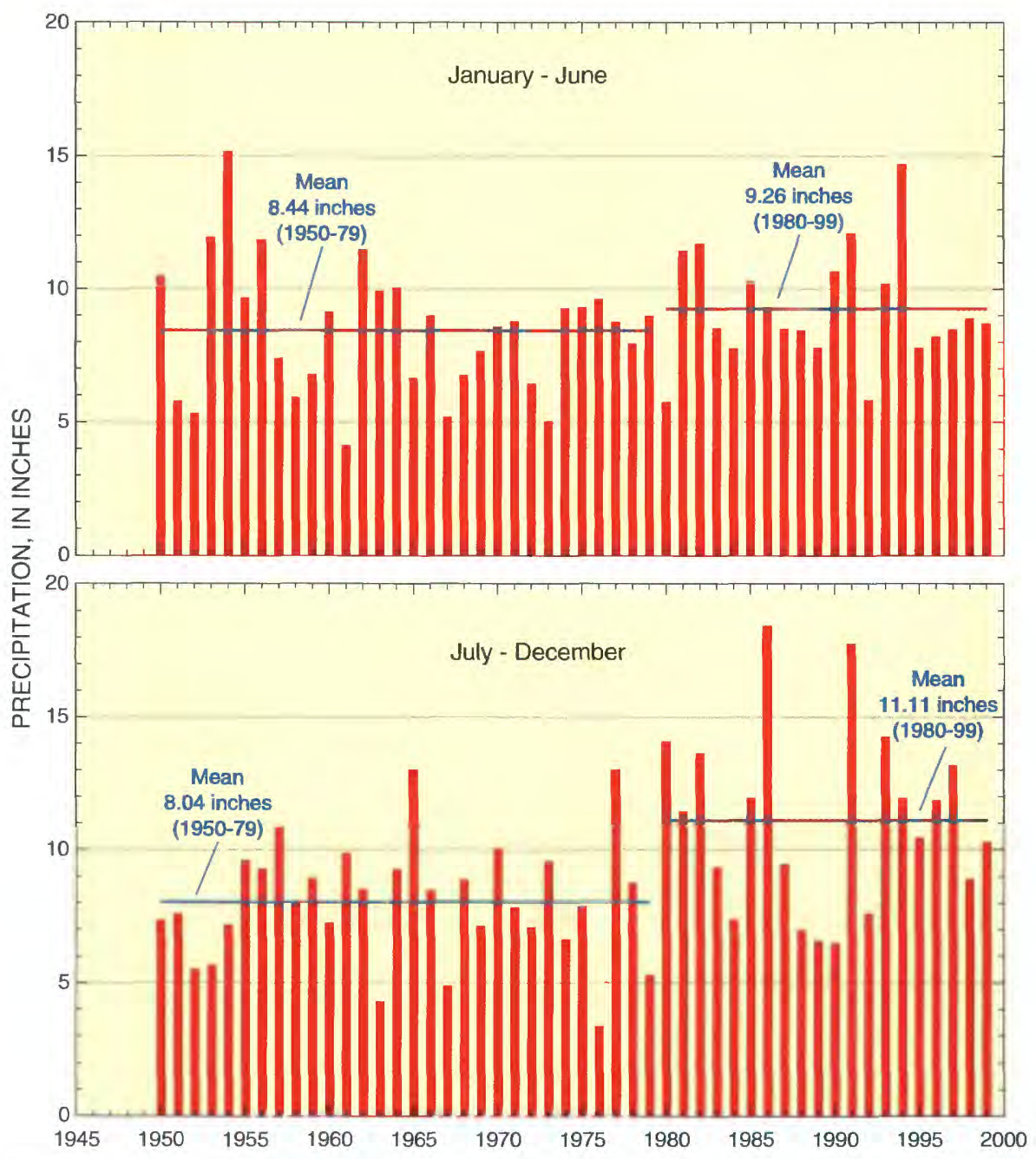

Figure 3. Devils Lake precipitation, 1950-99.

\section{Potential Effects of an Emergency Outlet}

Devils Lake currently is a terminal lake, and the lake levels in any year are affected by the storage and. therefore, the lake levels in the previous year. In contrast, the elevation of a river in any year is not affected by the elevation in the previous year. Because of this difference, standard statistical tools used to calculate values such as the "one hundred year flood" for rivers cannot be used for Devils Lake, and a tool that accounts for previous conditions was needed to evaluate the effects of an outlet on Devils Lake. As a result, the U.S. Geological Survey developed a simulation model for Devils Lake. This model uses historical climate conditions and the storage available in Devils Lake to generate 10,000 possible futures, called traces. Assuming the recent wet conditions will continue through 2015, the model indicates about a 2-percent chance Devils Lake will spill to the Sheyenne River before 2015 with no emergency outlet. With a 300-cubic-footper-second emergency outlet, the chance of a spill is reduced to less than 1 percent.

The potential for a catastrophic spill from the natural outlet to the Sheyenne River poses a threat for downstream interests. If Devils Lake reaches the spill elevation (about 1.459 feet above sea level), the contributing drainage area of the Sheyenne River near Cooperstown. N. Dak., will quadruple (from 1.270 square miles to 5,070 square miles) because the entire Devils Lake Basin then would contribute flow to the Sheyenne River. Also, water in Stump Lake (which becomes part of Devils Lake at an elevation of about 1.447 feet above sea level) is of much poorer quality than water in western Devils Lake, and significant volumes of water spilling from the natural outlet would cause serious downstream water-quality problems.

The potential discharge of spills from Devils Lake through Tolna Coulee to the Sheyenne River is shown in figure 4 . The amount of water that spills from Devils Lake is controlled by the geometry of the spill channel. Devils Lake can rise to an elevation much above 1,459 feet above sea level, and the magnitude of the spill will increase as the lake rises. Therefore, the 182 traces that exceed the spill elevation were separated into two groups--the 50 worst traces, for which Devils Lake exceeded 1.460.8 feet above sea level, and the remaining 132 traces, for which Devils Lake peaked between 1,459.0 and $1,460.8$ feet above sea level.

The top graph in figure 4 shows daily discharge averaged over 50 traces that exceed $1,460.8$ feet above sea level with no constructed west-end outlet. The 2 years shown are the year in which the lake peaks and the year after the lake peaks. With no outlet, discharge is about 2,100 cubic feet per second in late June, above 2,000 cubic feet per second for more than 1 month, above 1,000 cubic feet per second for more than 4 months, and above 400 cubic feet per second for more than 1 year. In terms of volume and duration, the spills would overwhelm ambient flow in the Sheyenne River with poor-quality water. Sulfate concentrations are several times the North Dakota water-quality standard of 450 milligrams per liter. As shown on the lower line, an outlet would not eliminate the effects of the potentially catastrophic spills, but the spill volumes and durations would be reduced substantially.

The bottom graph in figure 4 shows daily discharge averaged over 132 traces that are between 1,459.0 and 1,460.8 feet above sea level with no constructed westend outlet. With no outlet, discharge is about 430 cubic feet per second in July, above 200 cubic feet per second for more than 4 months, and above 100 cubic feet per second for more than 1 year. Although these discharges are not large enough to cause major flood problems in the Sheyenne River, the duration and high sulfate concentrations of the spills would cause significant water-quality problems downstream. The effects of the spills would be greatly reduced (or entirely eliminated) with the outlet. The outlet 

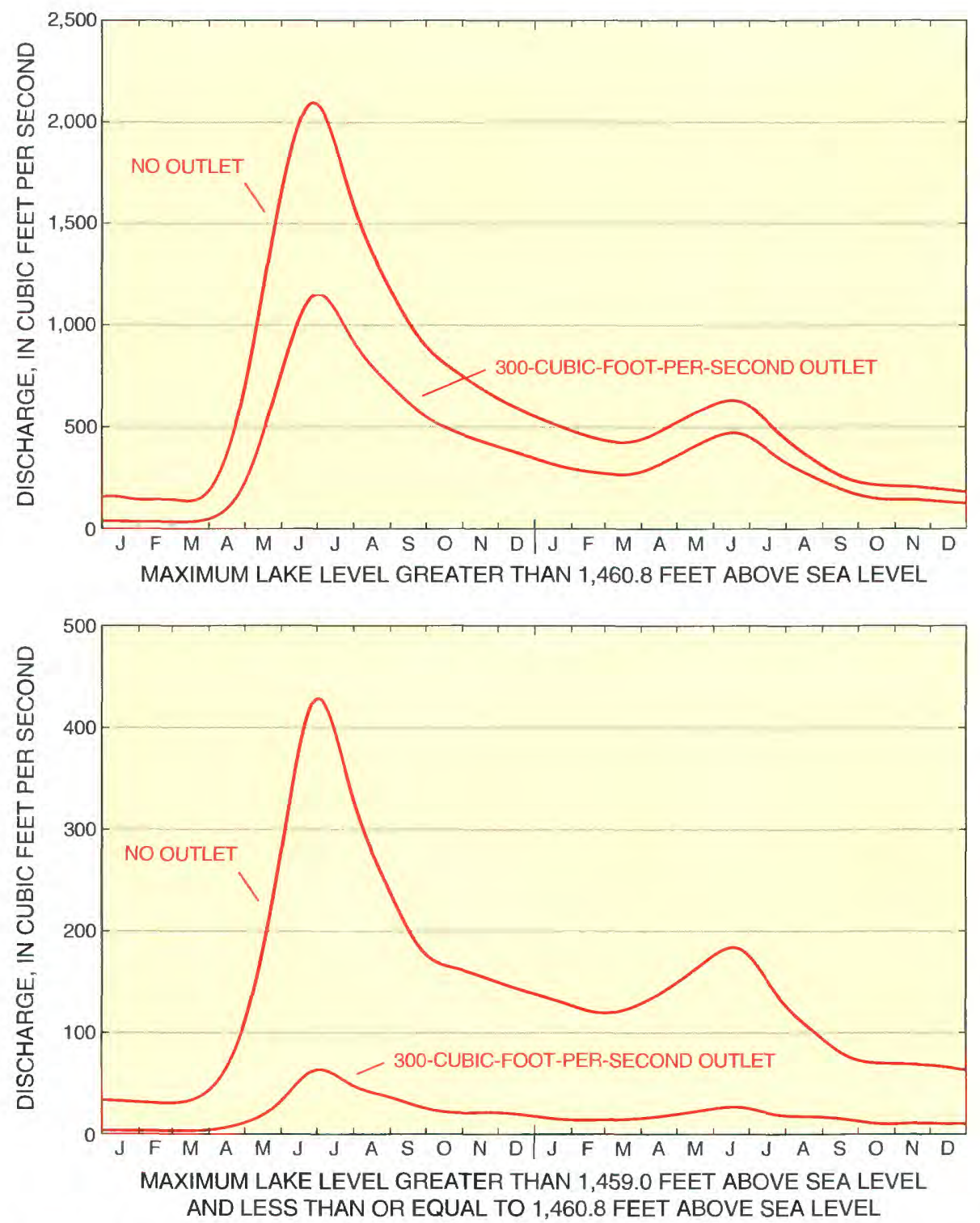

Figure 4. Discharge of spills through Tolna Coulee to the Sheyenne River. (Top graph shows average over 50 traces with and without an outlet; bottom graph shows average over 132 traces with and without an outlet)

completely eliminated the spills in 98 of the 132 traces shown on the bottom graph and greatly reduced the spills in the remaining traces.

If Devils Lake spills, discharge would flow through a channel to Tolna Coulee and then to the Sheyenne River. Because of the shape of the channel and the soil materials on its bottom (Murphy and others, 1997), erosion likely would commence immediately and could continue down to an elevation of about 1,447 feet above sea level. At that elevation, Stump Lake is no longer connected to Devils Lake, and the channel would reach a plateau that has a much milder downstream slope. Such an event would release up to 2 million acre-feet of water, about four times the volume of the 1997 flood at Lisbon, from the Devils Lake-
Stump Lake system. This water would be in addition to the flows described earlier.

-G. J. Wiche, A. V. Vecchia, and

Leon Osborne

\section{References and Further Reading}

Bluemle, J.P., 1991, Radiocarbon dating of beaches and outlets of Devils Lake: North Dakota Geological Survey Miscellaneous Series 75, $10 \mathrm{p}$.

Lent, R.M., and Zainhofsky, S.D., 1995 , Variations in surface-water quality in the chain of lakes and its tributaries, Devils Lake Basin, North Dakota, 1957-92: U.S. Geological Survey Water-Resources Investigations Report 95-4102, 87 p.

Murphy, E.C., Fritz, A.K., and Fleming, R.F., 1997, The Jerusalem and Tolna outlets in the Devils Lake Basin, North Dakota: North Dakota Geological Survey Report of Investigation No. 100, 36 p.

Sether, B.A., Vecchia, A.V., and Berkas, W.R., 1999, Spatial and temporal variability of dissolved sulfate in Devils Lake, North Dakota, 1998: U.S. Geological Survey Fact Sheet FS-096-99, 4 p.

Upham, Warren, 1895, The glacial Lake Agassiz: U.S. Geological Survey Monograph No. 25, 658 p.

Wiche, G.J., and Vecchia, A.V., 1996, Lake-level frequency analysis for Devils Lake, North Dakota: U.S. Geological Survey Water-Supply Paper 2469, $57 \mathrm{p}$.

\section{For more information contact any of the following:}

For water information:

District Chief

821 East Interstate Avenue

Bismarck, ND 58503

(701) 250-7400
For more information on all USGS reports and products (including maps, images, and computerized data), call 1-800-USA-MAPS.
Additional earth science information can be found by accessing the USGS "Home Page" on the World Wide Web at "http://www.usgs.gov". 